International Journal of Engineering \& Technology, $7(3.21)(2018) 330-337$
International Journal of Engineering \& Technology
SPC
Website: $\frac{w w w . s c i e n c e p u b c o . c o m / i n d e x . p h p / I J E T}{2}$
Research paper

\title{
The Concept Mapping in Learning Strategies: an Experimental Study of the Effect of Learning Strategies and the Attitude of the Students Towards Subjects and Ethical Learning Outcomes
}

\author{
Zainal Abidin Arief ${ }^{1}$, Ilham Firdaus Alviansyah Rinjani ${ }^{2}$ \\ ${ }^{I}$ Educational Technology study program, Ibn Khaldun University Bogor \\ ${ }^{2}$ Ibn Khaldun University Bogor \\ *Corresponding author E-mail: alvinrinjani@gmail.com
}

\begin{abstract}
The objective of this research is to find out the effect of learning strategies and the attitude of students on the Ethics course and its learning outcomes. The research is conducted to the students $(n=84)$ of The School of Politics Djuanda University Bogor. It is applied an experiment of $2 \times 2$ factorial designs. The results of this research are: (1) The students learning outcomes of the course by using concept mapping strategy is higher than those who used conventional strategy; (2) The learning outcomes of the students with positive attitude and used the concept mapping is higher than those who used conventional strategy; (3)The students with negative attitude, and used the concept mapping is lower than those who used conventional strategy; (4) There is an interaction effect between learning strategy and attitude toward students' learning outcomes of the course of public administration Ethics. Learning outcomes of students who have positive attitude toward the course of Public Administration Ethics can be improved by using concept mapping learning strategies.
\end{abstract}

Keywords: Concept Mapping; Learning; Strategy; Students Attitude.

\section{Introduction}

The educational process that focus on student creativity training, allows them to reveal their true nature and uniqueness. They tend to be confident, independent, enthusiastic, and precise. To recognize the potential creativity is quite important because everyone is born with the potential of inventing. Recently, the educational process is emphasized on discipline, logical and rational thinking of the left brain, and make the right brain's function not optimal. Thus, to optimize the creativity, concept mapping can used to maximize both sides: left and right brain.

The concept mapping in learning strategies is one of learning tools to help people study actively and integrate the old and recent knowledge by maximizing creative thought for students so that they can receive and digest the information. Concept mapping is an approach which is expected gives more advantages for active students` learning approach. This concept mapping aims to help students increase their memory while taking note with adding images or symbols in the lessons to activate both functions of the left and the right brain. Therefore, the lecturers can apply the concept mapping as an alternative of the effective learning tool.

\subsection{Scope of the Research}

This research was limited to explain the factor of learning strategies and students' attitude towards the Ethics of Public Administration subject. Besides the factor of the students`attitude itself, this research also reviewed the learning outcomes of Ethics of Public Administration subject.
Hence, the main point of this research which was formulated in the form: The effectiveness of learning strategy, student attitude and learning outcomes of the ethics of public administration subject, were the experimental studies of concept mapping strategy for the learning outcomes of FISIP student of University Djuanda Bogor.

\subsection{Research Problems}

Based on the background and scope of the research above, the problem of the research formulated as below:

a) Were there differences in the learning outcomes among students who taught by concept mapping strategy and by conventional strategy?

b) Were there differences in the learning outcomes among the student of positive attitude who taught by concept mapping strategy and by conventional strategy?

c) Were there differences in the learning outcomes among the student of negative attitude who taught by concept mapping strategy and by conventional strategy?

d) Was there a correlate between learning strategy and the attitude of students towards learning outcomes?

\subsection{Research Objectives}

The objectives will be achieved from this research is to investigate and obtain empirical data about:

a) The differences in the learning outcomes among students who taught by concept mapping strategy and by conventional strategy. 
b) The differences in the learning outcomes among the student of positive attitude who taught by concept mapping strategy and by conventional strategy.

c) The differences in the learning outcomes among the student of negative attitude who taught by concept mapping strategy and by conventional strategy.

d) The correlation between learning strategy and the attitude of students towards learning outcomes.

\section{Literature Review}

\subsection{Learning Strategies}

In the perspective of educational technology, learning means containing concepts that influence the way of thinking, acting, research and development of learning then known as learning technology. Learning means creating a situation that can stimulate students to think and solve the problems. In the concept of educational technology, the term learning is distinguished by the teaching. The term learning then developed into instructional activities Thus, learning is an attempt to manage the environment deliberately in order to make the participants can behave as expected, besides teaching is an active effort to guide which occur in certain situations. Therefore Yusuf Hadi Miarso(1) emphasized that learning and teaching is a science and art as well. A Person with scientific aspects only may not necessarily apply well. Good

learning programs must fulfill the criteria of attractiveness, effectiveness, and efficiency which is prepare with good plan. Therefore we need a strategy, a term that used among military. Strategy in military defines as the art of planning a military campaign in a war, especially in relation to the movement of land and sea forces toward a favorable target for fighting. Therefore, the strategy can also be interpreted as an outline of the bow or act to achieve the goals that have been set(2). Based on the above definition, it can be formulated as a basic strategy that refers to the planning and management of a problem or an activity in order to achieve the objectives and predetermined. If it is applied in the context of learning can be defined as: (1) system of teaching-learning approach which is considered the most effective way to achieve the goal, can be used as teachers/lecturers guideline in planning and organizing the learning experiences; (2) the procedures, strategies, and techniques of teaching methods which is regarded as the most effective, efficient, and productive for teachers` guideline. The word 'strategy' itself adapted and used by educational experts to plan and manage the education system, especially in the teachinglearning process which then known as the learning strategies.

Mudhoffir Ali (3) stated that the learning strategy is one of the learning methods to transfer information, select resources, to define and explain the role of the student. Meanwhile Seels and Richey(4) defines learning strategies as specifications of the selection of sequencing occasions and activities in the lesson. Dick and Carey(5) stated that the learning strategy contains five major components, namely (1) the introduction of learning activities that include motivating students, the delivery destination is done verbally or in writing, provide information about the prerequisites that must be owned by the student before attending the lesson, (2) the delivery of information that focuses on content, sequence of subject material, the teaching stages (3) the participation of students in the form of training and feedback, (4) providing a test that aims to control the achievement of learning objectives, and (5)the follow-up activities in the form of enrichment or remedial. Learning strategies are also used to cover many aspects in organize the information and decide about how to present it. There are three main activities in the learning strategy; (1) sequencing of subject material, (2) the selection of learning media, and (3) presenting the lesson material. The subject material's sequence is determined by the analysis, the instructional media should consider the context of the learning process, the skills that will be taught, and the practical situation. The presentation of the subject material based on several considerations, such as (1) the age of the students, (2) the complexity of the material, and (3) the types of learning activities that will occur. Thus the learning strategy is the way that used by teacher/lecturer in carrying out the more effective and efficient learning process to achieve the objectives. Learning strategies play an important role in learning activities in the classroom. What is the relationship between strategy and strategy in learning activities? Strategy refers to the general model in learning activities between teachers and students, while the strategy shows the specific ways of how learning can be implemented as well as possible to achieve the stated goals(2).

Meanwhile, Gagne and Briggs(6) define the term of learning strategies as "events of instruction" which is the sequence to set the external conditions to make the information is is acceptable to the learner. There are nine nine sequence of instructional activities, they are (1) gives the motivation or attention, (2) explain to students, instructional goals (3) increasing the competence prerequisite, (4) gives the stimulus by provide learning materials (problems, topics, concepts), (5) gives learning instructions (how to learn), (6) occur the student performance, (7) gives good feedback, (8) evaluate performance, (9) concluded. Atwi Suparman(7) explains that there are four instructional strategy or understanding of basic elements, namely (1) the sequence of instructional activities, (2) instructional strategies, (3) instructional media, and (4) the time during the instructional activities. Thus the strategy is the lesson plan with a principal learning activity based on the results of theoretical and empirical studies which addressed to the students individually. Meanwhile, the technique or strategy is a procedure used in the learning process, and focus on some valid approach, to improve the learning process. Then the material or media is a tool to present material and design to be in strategy and techniques and strategy. The strategy according to Yusuf Hadi Miarso(1) is a comprehensive learning approach in a learning system, contained general guidelines and framework activity to achieve the general lesson which explained from certain learning theory. For example, the strategy used to increase the interest and ability of reading and writing. This strategy should be integrated into each subject even though there might be special guidance for it. Based on the opinion of some authors, it can be conclude that the above can learning strategies is concerning (1) the sequence of learning activities, which is the sequence that must be followed in presenting the learning material, (2) instructional strategies or techniques, procedures and techniques relating to the organization of learning material, (3) instructional media that is associated with learning tools and materials used in the learning process, and (4) function, which involves the separation roles and tasks between teachers and learner in the learning process. The fourth element is a unity that cannot be separated from one another; in the form of unity in the learning process. Thus learning strategies that defined in this research is the common pattern between the teacher's activity and the learners in the learning to achieve the objectives of Ethic public administration subject, which is a combination of sequence of activities, the applied strategies, the media used, and function between the lecturer and the students in the whole learning process. In the research of this strategy theory, the focus is in concept mapping learning strategy and conventional learning strategy.

\section{a. The Nature of Conventional Strategies}

Conventional learning strategies usually focus on the lecturer, as the lecturer always use a sequence of learning activities descriptions, examples, and exercises. Learning activities starting from the description of the lecturer to explain the subject matter with examples, then students listen, take notes, then asked, and ended with a feedback. Therefore conventional learning strategy is a lecturer's center. The lecturers always do direct instructional approach, and the students just listen the material. Also, in terms of developing the skills to mastering the material presented, continue with advance learning supervise by the lecturers(7). In terms of 
determining what strategies will be used, it is entirely based on the goals. The learning`s goals are intended to create the behavior changing in the learning process. Changing behavior as a comprehensive function of environmental conditions as the result of practice and experience(8). Experience in the learning process is the interaction between the individual and the environment. Such interactions will encourage interaction among learning participants. Indeed, conventional learning strategies more emphasis on building relationships that can be controlled and observed. Therefore, conventional learning strategies typically are routine and formal. The main activities are verbal teaching and do demonstrations. Lecturers are the center and just few of students can ask the questions. Lecturer is the center of everything, including the responsibility and authority to determine the issue of audience.

In the case of conventional learning strategy, Robert J. Stahl(9) gives the characteristics of learning activities as follows: (1) conduct activities for themselves (2) view of studies focus on the (3) listening intently (4) teaching materials obtained from the lecturer (5) working individually (6) learning attentive (7) full authorities lecturer (8) passive learners. Meanwhile, according to Atwi Supaman(7), the conventional learning strategies lecturers will conduct face-to-face learning process as follows: (1) start the lesson by reviewing the last lesson (2) continued by explaining the purpose of the lesson briefly (3) teach new material step by step, so that the learner can follow the whole process of learning (4) gives instructions and information clearly and in detail (5) give a chance to practice the knowledge they have gained (6) gives a question and review the student understanding through their responses of various questions (7) providing feedback. However, conventional learning strategies can not be abandoned in implementing the learning process. This deliver a good advantage for the lecturers also on this learning program, while this strategy emphasis on achievement of the target material and quickly delivered and accepted by participants of the learning.

\subsection{The Concept Mapping Learning Strategies}

In the concept mapping process, the student is expected get involve of the learning process, while the teacher act as a facilitator and moderator. In the perspective of educational technology, learning processes oriented on the needs, abilities, and characteristics of the student, they must be actively building an idea or ideas. Learning is an interactive process that can meet the individual needs of each student, students need to be actively involved in the learning process. Concept mapping helps the students to be more active and critical to the new concept, they will ask the relationship between the new and old concept. Walker(10) says that mapping concept firstly used by Joseph d. Novak from Cornell University in 1960. Concept mapping has the original form how to learn, which is called ancestor or build ideas. Especially the main initiator with primary knowledge uses as a frame work to learn about new knowledge. The nature of the concept mapping is how to think effectively to what is learned. Novak subsequently stated that the concept of mapping is to identify how to think, how to look the relationship between existing knowledge. Concept mapping can explain the shape of the mistakes made by individuals and help students to understand better and interpret the meaning on the subject of the existing problems. Walker also said that the concept mapping is similar to a flow chart, it is a concept of how to present and organize knowledge. Meanwhile, according to Martin(11), mapping concept is representative of two arrangements standard that demonstrate the organizational structuring of the relationship between the concepts involved in a form of discipline or sub-discipline. Mihkilson that quoted by Walker said that the mapping concept is one of the tools to learn the knowledge of how to integrate the old and the new knowledge. By concept mapping, it can be identify how far the knowledge of students about a concept, so teachers can provide additional or corrections to the knowledge of students. The students` knowledge about a concept can be described by concept mapping. Usually, the concept map- ping divided into a circle in the center to represent various concepts and relationships / lines represent relationships or problems in each concept. The words used to naming the group to emphasis the image on the existing relationships. Concept mapping can form in visual graphic to help students represent how the creator thinks about the subject, topic, and others. This illustrates how the set of knowledge for the benefit of the individual, the concept mapping interpreted as visual images that help students to clarify the link between new knowledge with prior knowledge of the subject. Concept mapping can help students to organize the ideas and scientific concepts to demonstrate their understanding concern to the relationships between those concepts. Concept mapping is also an alternative way of teaching that allows the formation of cognitive strategies to help the learner's ability to think internally and organize in solving problems, making decisions critical thinking, and creative. Concept mapping can change your lifestyle, enabling them to capture the flow of creative ability, innovative, and productive. Meanwhile Joyce(8) said the concept mapping is a great way to help achieve the highest performance in all aspects of life. This is in accordance with the results of the study Buzan(12) about mapping concept, which was developed in the early 1970s that is a concept mapping as a tool to help people record more effectively. In using these tools Tony Buzan realized that this finding is a great new way to improve the thinking ability of the student. Benefits of mapping concepts may be well understood when compared to the techniques we learned to generate ideas and noted the traditional way of writing the outlines of the problem.

Concept mapping, besides to improve the freedom of association can also teach an innovative and comprehensive approach to mapping ideas, students create their own notes system that involves drawing, color, and key words that are similar to mind mapping. Students are excited to realize that their own intuition has been improved and systematized that make them able to explore new dimensions of flexibility and precision of thought(8). Concept mapping effects very extravagant; and can pave the way to the entire of the brain, enabling activities arranged within minutes, encouraging the emergence of creativity, breaking down the limitations of writers, and generating brainstorming mechanism. From these several definitions, it can be conclude that the learning strategies with concept mapping is as a tool of visual imagery that can help students to clarify the link between new knowledge with basic knowledge in advance. Concept mapping can help students organize the ideas and scientific concepts to demonstrate their understanding regarding the relationship between these concepts. Concept mapping is also an alternative way of teaching that allows cognitive strategies to help the learner's ability to think creatively internally and organized in solving problems and making decisions. Concept mapping learning strategy in this study conducted in the stages as below: (1) Introduction; includes a) The lecturer inform the and outlines of the course in face to face sessions, b) The lecturer tell the main topics / keywords to be discussed, (2) core activities; includes a) Lecturer gives the task of the case or main theme to be completed by student in groups, b) students discuss and solve the problem according to the given topic, c) The lecturer intensively monitor the process of discussions of the groups. (3) Conclusion with brainstorming: (a) each group provides problem-solving solutions in the form of conclusion (b) brainstorming with a lecturer as a form of active student reflection, critical, creative and innovative.

\section{Learn More with Systematic Mapping Concept}

Systematic learning will make students more creative, because everyone is full of creativity and innovative. Everyone has different creativity but the diversity and originality with something where everyone makes excuses to not do anything, this shows that everyone has a tremendous amount of talent that can be applied in a more positive direction. The image below reflects the education system which prioritizes the information. 


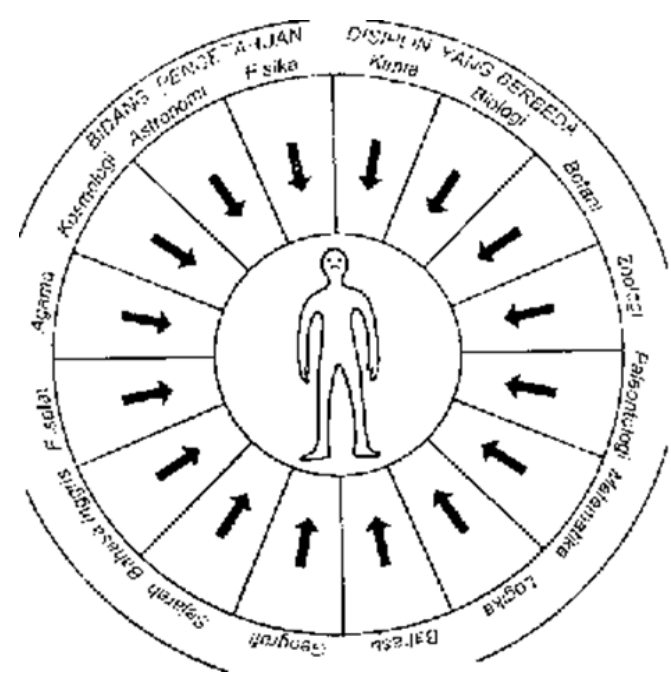

Fig. 1: The education system that provides information according to Different Fields that surround the learner (adapted from Tony Buzan(12)

As shown in the figure above, we concentrate too much on the information about the field of knowledge that is 'separate'. This approach has also been reflected in the standard learning techniques recommended in the School and University. Unlike the concept mapping learning strategy, we need to start from an individual to outside, instead of focus with books, formulas, and examination. We have to focus to teach how everyone can learn efficiently. Therefore, the concept mapping learning strategy is form a new style of educational system with the emphasis to reverse the previous education. The following picture tells about new style learning with the concept mapping in learning strategy.

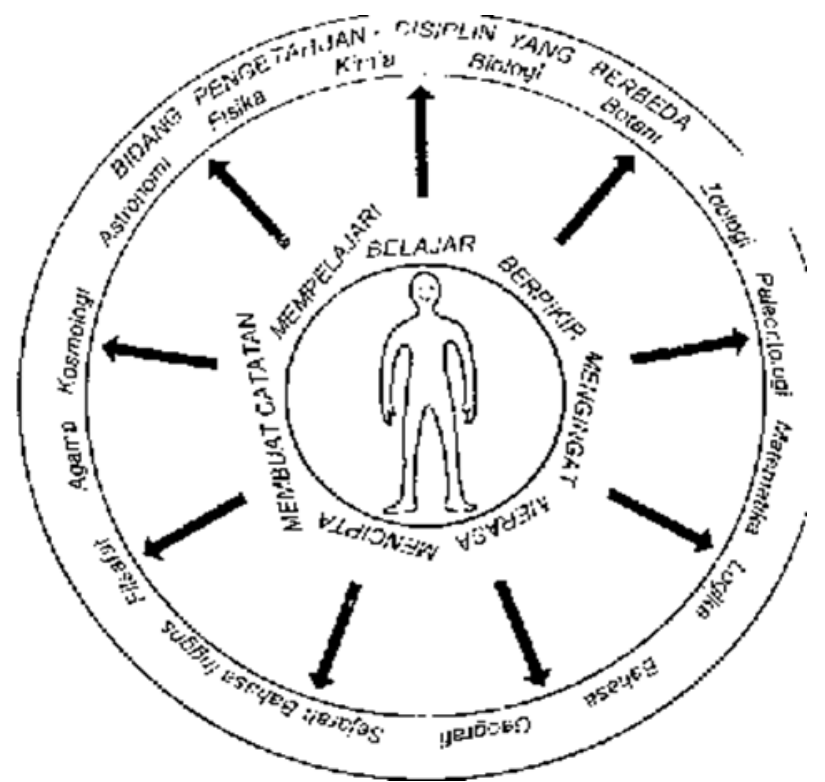

Fig. 2: New Style education system is reversed where the Different Fields covered by the learners (adapted from Tony Buzan(12)

If we look at the picture above, everything doesn't have to be "taught" or "stuffed". Everyone will be able to explore knowledge with their own, personal supervision is only asked when needed. The other advantage of mapping concepts in learning strategies is make the learning process become easier, more meaningful, more fun, more productive, effective and efficient. The purpose of learning with concept mapping learning strategy; firstly, to create a meaningful learning with relate the current record materials and good memory. Secondly, the materials will be more meaningful by adding image and symbol in the note so that the materials comprised a meaningful and logical component (Ausebel, 1978: 3839).

Concept Mapping and Brain Hemisphere Functions
Buzan (12) said that the human knowledge achievement may still less than $1 \%$ of what we need to be known. Meanwhile, Joyce (8) said that there is mystery core which is not revealing yet closer to the mind. The coverage is almost as spacious as the space. The mass of the wrinkled brain, bray, and weight approximately 1.5 kgs, there are about 10 to 15 billion nerve cells that are capable of making 108000 tracks. In the book titled "The Brain" (12) stated that the human brain can store more information than the entire library in the world. Later in The Three-Pound Universe, Judith Hooper and Dick Teresi compared the brain with the universe. They stated, 'it's the brain was the universe'.

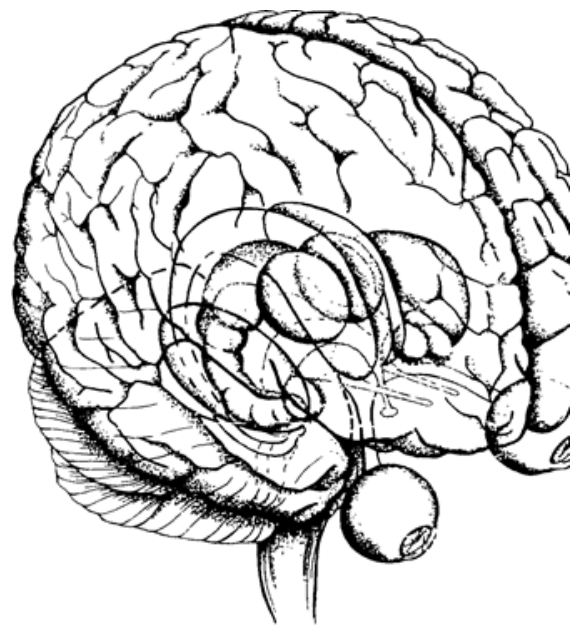

Fig. 3: The human brain is a mysterious and complex (adapted from Tony Buzan(12)

Comparing the brain with a bowl of jam that had hardened so that its surface is completely flat. When entering the thoughts, the information manages themselves. This is like pour a spoon of hot water onto the surface of the jam, after pour it several times then the surface will full of channels, dent, and water flow. The next water droplets (the new information) will automatically flow into the channel that has been formed. Then, its only a few information (water) to activate the entire channels. This is the process of pattern recognition and pattern refinement. When entering the mind, the information goes into a channel, a pattern even most of the information is outside the line, the patterns will be activated. The mind is automatically 'correcting' and 'completing' the information to select and activate a pattern. Creativity arises while we increase the bowl of jam and pressing the water (information) flows into new channels and create new relations. If the brain must relate the information efficiently, then the information should be structured in such a way as to be able to enter the small hole as easy as possible. This means if the brain works with key concepts through the mapping of concepts by means of interconnected and integrated. Combine information from previous obtained and observed that the brain handles information better if information is designed in accordance with the "slot" mapping concepts and also observe the information of the chapter per chapter about the nature of dimensional mind, find that the records are more "creative" and holographic will much more easily understood, appreciated, and memorize them.

Concept Mapping and the Left and Right Brain Membranes

In the early 1960s, Roger Sperry (12) a psychologist at the Institute of technology of California, observe to an epilepsy sufferers, he assumed that the epilepsy suffer people is the effect of uncertain electric shocking between the two hemispheres of the brain. It cuts corpus callosum that connects the two hemispheres of the brain. The operation is successful and remains normal. Research on the cerebral hemispheres of the brain revealed that the function of brain which stimulus the respond of music, rhyme, and emotion. The nature of the cerebral right brain lately, the term right-brain has been used as a popular way to express the creative, artistic, and Immaculate, as opposed to the parts of the left brain is consid- 
ered boring, analytical, and stiff. Here's a picture of both cerebral hemispheres membranes left and right brain.

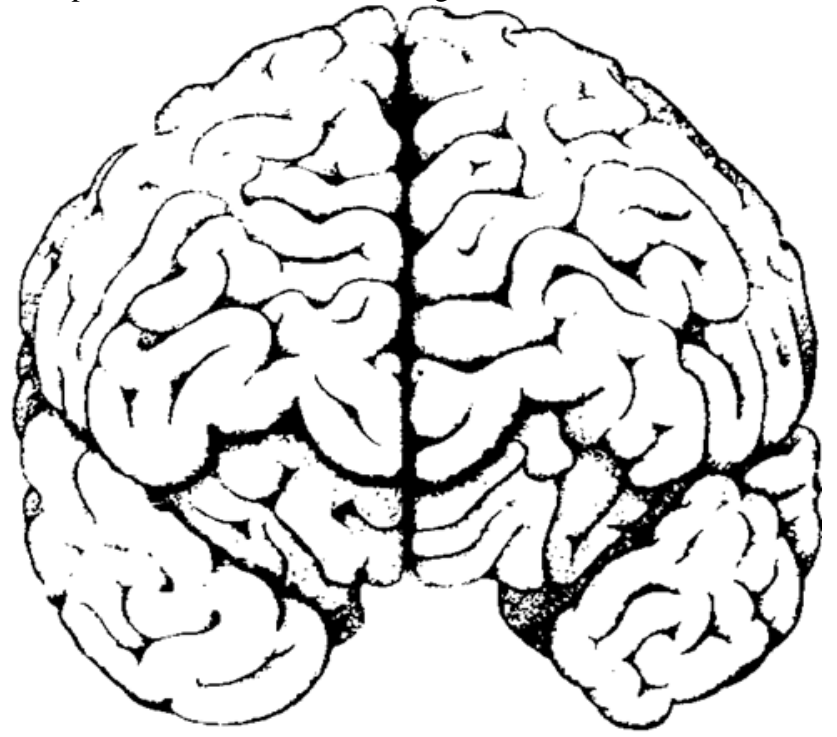

$\mathrm{R}$

L

Fig. 4: The left Brain Hemisphere membranes and right-brain, adapted from Tony Buzan(12)

Left

Right

Said

Logic

Awareness

Figure of imagination

Sequence

Climes

rhythm

space

Gestalt (whole picture)

reverie

analysis of linearity color

list

Although the brain has two hemispheres, each has its own specialty. The most important thing is the left brain and right brain actually is just a metaphor to the specialization which tends to be handled by hemispheres. Both hemispheres determine our way of think. Creativity arises from the extraordinary interaction of both hemispheres. The emphasis on the right brain's properties aim to balance our education system which tend to give emphasis on the left brain, such as the recitation, language proficiency, arithmetic, logical thinking, and sequence. We have been taught to find the answer and say "right". Even now days the school offers a few opportunities to practice imagination and ability to think of alternative. Therefore, in an effort to develop an approach that is more on the whole both hemispheres, so Sperry and Ornstein, cited by Buzan, has done a research that changed history and won the Nobel prize that the two sides of two membranes of the brain that are connected by a complex network of nerve cells The Corpus Callosum, predominantly associated with the different types of mental activity. Based on the results of the study, the left brain membranes of most people is associated with logic, words, lists, numbers, linearity, analysis, and other activity called "academic". While the right brain is in "alpha waves" or a State of sleep, ready to help. The right brain membranes associate with the rhythm, imagination, color, reverie, space awareness, gestalt (overall picture) and dimensions. Furthermore Buzan said that the left and right brain membranes provide additional support to the work you will do on the memory system, recording and communication, as well as high level concept mapping, because each of these areas is important to use.

Based on the research of Buzan, if we look at how the research on the brain gives more strength on recent issues. According to the research that the brain handles information better if the information is designed for 'small hole' through the concept mapping process, consideration of research of left and right brain membranes by Roger Sperry, Robert Orntein and Eran Zaidel said that this research will lead to the conclusion that: techniques of organizing mind, and making the record which is designed to fulfill the needs of the whole brain should include not only words, numbers, sequence, and linearity, but also the color, dimensions, rhythm, visual, spatial awareness, etc., in other words is by concept mapping. From any perspective, if one approaches the problem, more of the nature of the words and information, the function of the ability to remember, holographic model of the brain, and brain research recently, in the end the conclusion remains the same, to make use of the capacity of the brain completely, to consider that each element enclosing the overall, and integrating it. Concept mapping process paves the way for natural mind penetrates far deeper and let the free association. Therefore, the way it works is similar to psychotherapy. Concept mapping can open an emotional right brain hemisphere, and pour the contents of the mind by associating freely, but we only write down the key word when the moment feels "well this is it", it means that the conscious had found what should be written. Such as "Psychotherapy", although it is not a primary treatment for psychological disorders, concept mapping can help to understand who we are and how the mind works. Concept mapping become a tool to listening ourselves, to listen to the inner dialogue that continuously takes place in our minds to develop the creativity.

\section{Student attitudes}

The attitude can be defined as a person's judgment towards certain object in a positive or negative. The outline of the attitude expressed above is something very subjective and very personal which is based on the conviction. The attitude is defined as an individual's tendency to respond in a certain way towards the situation of things, ideas, people, and issues, as stated by Lau, James B and AB Rami Shani (13) beside, Kiesler Collins and Miller, as quoted by Fishbein and Ajzen(14) mentioned that attitude as a predisposition study to give reaction continuously to an object. The given reaction can be positive or negative. (Keller, 2000 20) both can be controlled to present the hidden potential in improving the success and self-satisfaction. An attitude usually influenced by various factors such as experience, knowledge, feelings, emotions, ways of thinking, needs and goals you want to achieve. Attitude can also be interpreted as a tendency in responding in a like or not of any objects. Krech and comrades (Zanden 1984: 121) mentioned that there are three components of attitude i.e. cognition, conation and affection. Components of cognition show how someone finds out about an event, circumstances, beliefs, and ideas about things. While the components of the affection is about feelings and emotions on actual objects, events, and circumstances Conation is tend to act with happening object or events. According of the statement above, Schermerhon, Hunt and Osbon (1991: 115) stated that the components of attitude consist of three kinds, that are: (1) the cognitive component, is a beliefs and values that concern to the information and noticed observations, (2) an affective component, which is a special feeling to the personal influence of the antecedent conditions, (3) behavioral components, a tendency to show reaction (behavior) in a certain way in order to respond the feelings.

According to Baron and Byrne (1984: 159-163) there are two important things to keep to be a pretty good prediction's tool for the behavior of a person that are: first, attitude object must be special and second, attitude object should directly related to the interests of the person. While Kendler(15) stated that a person's attitude is a person's tendency to give a reaction to the given action in his own way. Someone in building an attitudes is acceptable or not acceptable toward something objects, there are a number of reasons, usually because someone already knows the object or new ideas that did not match with the situation, even useless. Because of that attitude is pleased or not pleased is a mental activity. Roger M Shoemaker (16) said that if mental activity at an early stage is mainly the introduction or cognitive functioning, mental activity on the primary affective persuasion phase. So before someone knowing something new ideas, he cannot show a certain attitude to him. The attitude is acceptable or not acceptable is usually followed by behavioral, Therefore the attitude can be seen as a reaction to the affection of the object at hand based on the results of observation, reasoning, and so was born someone's 
conception, ideology, or the views of the object resides. Attitude is the readiness or tendency to think, feel, and behave on any reference objects(17). Based on the description above it can be concluded that the definition of the attitude here is the behavior that leads to a person's tendencies or mental readiness to react both positive and negative when exposed to a specific object. It gives positive respond in accepting or enjoying but also it will give negative respond while rejecting or dislike, then a concept, ideology and judgment come out to the certain object. The attitude in this research is referred to the mental readiness of students to react and respond to Ethics Public administration course that reflected a positive or negative response based on students` point of view.

\section{Methodology/Materials}

The method used in this study is the experimental study. The variables in this study consisted of (1) Variable-free learning strategies (2) The dependent variable learning outcomes and (3) variable attribute is attitude. The design used in this study is a $2 \times 2$ factorial design

Table1: Problems of Constellation Research

\begin{tabular}{|c|c|c|c|c|c|c|}
\hline \multirow{2}{*}{ Student's Attitude(B) } & \multicolumn{3}{|c|}{ Concept Mapping } & \multicolumn{2}{|c|}{ Conventional } & \multirow{2}{*}{ Line Total } \\
\hline & \multicolumn{3}{|l|}{$\left(\mathrm{A}_{1}\right)$} & \multicolumn{2}{|c|}{$\left(\mathrm{A}_{2}\right)$} & \\
\hline \multirow{2}{*}{$\frac{\text { Positive }\left(B_{1}\right)}{\text { Negative }\left(B_{2}\right)}$} & \multicolumn{3}{|l|}{$\mathrm{A}_{1} \mathrm{~B}_{1}$} & \multicolumn{2}{|c|}{$\overline{\mathrm{A}_{2} \mathrm{~B}_{1}}$} & \\
\hline & \multicolumn{3}{|l|}{$A_{1} B_{2}$} & \multicolumn{2}{|c|}{$\overline{\mathrm{A}_{2} \mathrm{~B}_{2}}$} & \\
\hline \multicolumn{3}{|l|}{ Column Total } & & & & Total \\
\hline \multirow{2}{*}{\multicolumn{2}{|c|}{$\begin{array}{l}\text { Treatment: } \\
\text { A1B1: Group of students taught by concept mapping learning } \\
\text { strategy and students with positive attitude } \\
\text { A2B1: Group of students taught by conventional learning strategy } \\
\text { and students with positive attitude. } \\
\text { A1B2: Group of students taught by concept mapping learning } \\
\text { strategy and students with negative attitude }\end{array}$}} & & $\begin{array}{l}\frac{\sum \mathrm{X}^{2}=}{X}= \\
\mathrm{s}=\end{array}$ & $\begin{array}{l}13056 \\
24,857 \\
2,007\end{array}$ & $\begin{array}{l}13697 \\
25,476 \\
1,834\end{array}$ & $\begin{array}{l}26753 \\
25,167 \\
1,921\end{array}$ \\
\hline & & $\sum$ & $\begin{array}{l}\mathrm{n}= \\
\sum \mathrm{X}= \\
\sum \mathrm{X}^{2}= \\
\bar{X}= \\
\mathrm{s}=\end{array}$ & \begin{tabular}{|l|}
42 \\
1113 \\
29809 \\
26,5 \\
2,23
\end{tabular} & $\begin{array}{l}42 \\
1074 \\
27624 \\
25,571 \\
1,99\end{array}$ & $\begin{array}{l}84 \\
2187 \\
57433 \\
26,036 \\
2,112\end{array}$ \\
\hline
\end{tabular}

\section{and students with negative attitude}

Treatment applied in this study: (1) learning strategy which consists of conventional learning strategy and concept mapping learning strategy, (2) the attitude of students consisted of two choices: positive and negative. Learning strategies and student attitudes are the predictor variables. While the treatment is reviewed in this research that includes course material, teaching and treatment which will be described below: the course material used in this research is the ethics in public administration subject on the even semester in college students majoring in public administration, University of Djuanda Bogor. The main topic that stated in this research is the "Fundamental of ethics for the officials as planners and implementers of the state administrative" The material is presented in the technical operation of instructional design composed of researchers, each in group using concept mapping learning strategy and the conventional strategy with 14 times the frequency of face to face meetings. Each meeting consisted of 2.5 hours (150) minutes, equivalent to 3 credits. Each test is held midterm exams (UTS) and final exams (UAS). Based on the matrix of experimental research design used in this study is a $2 \times 2$ factorial design, then it means there are 4 (four) cells (group) of students who are given different treatment.

\section{Results and Findings}

\subsection{Description of Data}

Descriptive results of the study can be seen in the following table2,

Table2

\begin{tabular}{|l|l|l|l|l|}
\hline \multicolumn{2}{|c|}{ Statistic Source } & $\mathbf{A}_{\mathbf{1}}$ & $\mathbf{A}_{\mathbf{2}}$ & $\sum$ \\
\hline \multirow{3}{*}{$\mathrm{B}_{1}$} & $\mathrm{n}=$ & 21 & 21 & 42 \\
& $\sum \mathrm{X}=$ & 591 & 539 & 1130 \\
& $\sum \mathrm{X}^{2}=$ & 16753 & 13927 & 30680 \\
& $\bar{X}$ & 28,143 & 25,667 & 26,905 \\
& $\mathrm{~S}=$ & 2,455 & 2,153 & 2,304 \\
\hline & $\mathrm{n}=$ & 21 & & \\
$\mathrm{~B}_{2}$ & $\sum \mathrm{X}=$ & 522 & 21 & 42 \\
& & 535 & 1057 \\
\hline
\end{tabular}

Description:

A1 = students of Public Administration taught by concept mapping learning strategies

A2 = students of Public Administration taught by conventional learning strategies

B1 = students of Public Administration with positive attitude

B2 = students of Public Administration with negative attitude

$\equiv \quad$ number of samples

$=$ Mean score learning results

$\mathrm{S} \quad=$ Standard deviation

Based on a $2 \times 2$ factorial design, there are total eight groups where the result mentioned as follows: (1) the results of the study the ethics of public administration student of FISIP UNIDA Bogor who was taught by using concept mapping teaching strategy (2) results of study the student administration ethics UNIDA Bogor taught by using conventional learning strategies; (3) the results of the study the ethics of public administration student of FISIP UNIDA Bogor who have positive attitude; (4) the results of the study the ethics of public administration student of FISIP UNIDA Bogor who have negative attitude; (5) the results of studying the ethics of public administration student of FISIP UNIDA Bogor who have positive attitude and taught by using mapping concept learning strategies; (6) the results of the study the ethics of public administration student of FISIP UNIDA Bogor with positive attitude and be taught by using conventional learning strategies; (7) the results of study the ethics of public administration student of FISIP UNIDA Bogor who have negative attitude and taught by using mapping concept learning strategies; and (8) results of study the student administration ethics UNIDA Bogor who have negative attitude and taught by the conventional learning strategies.

\subsection{Hypothesis Testing}

Hypothesis statistical testing in this study conducted by using analysis of variance (ANOVA) two lanes which followed by a Tukey test. The varian analysis two lanes is used to examine the main effect and interaction effect of independent variables of 
learning strategies and student attitudes towards dependent variable of learning outcomes. Furthermore, the result of data analysis ANOVA two lanes can be seen in the following table.

Summary of the Analysis of Variance Table Data Results Learn the Ethics of Public Administration

\begin{tabular}{|l|l|l|l|l|l|}
\hline Varians & $\mathrm{dk}$ & $\mathrm{JK}$ & $\begin{array}{l}\mathrm{RJK} \\
(\mathrm{Jk} / \mathrm{dk})\end{array}$ & $\mathrm{F}_{\text {amount }}$ & $\mathrm{F}_{\text {Table }}$ \\
\cline { 5 - 6 } & & & 0,05 \\
\hline $\begin{array}{l}\text { Per Column } \\
\text { (Learning Strategy) }\end{array}$ & 1 & 18,107 & 18,107 & $4,012^{*}$ & 3,96 \\
$\begin{array}{l}\text { Per Line (Attitude) } \\
\begin{array}{l}\text { Column and Line } \\
\text { Interaction) }\end{array}\end{array}$ & 1 & 63,44 & 63,44 & $14,057^{*}$ & 3,96 \\
\hline $\begin{array}{l}\text { Per group } \\
\text { In group }\end{array}$ & 3 & 50,298 & 50,298 & $11,145^{*}$ & 3,96 \\
\hline TOTAL & 80 & 361,05 & 131,85 & $9,74^{*}$ & 2,72 \\
\hline
\end{tabular}

Description:

Based on the Table above, the results of the two lanes of analysis of variance can be explained as follows:

1. The zero Hypothesis (Ho), which is stated that there is no difference between the results of studying the ethics of public administration which taught by concept mapping learning strategies and conventional learning strategies reject $(\mathrm{Fo}>\mathrm{Ft})$. In other words that there is a difference in the results of learning administrative ethics between students who are taught by using concept mapping learning strategies and by using conventional learning strategies and the difference is significant.

2. The zero Hypothesis (Ho), which is stated that the average score of student of the ethics of public administration with a positive attitude and taught by using concept mapping learning strategy had no differences with the student who taught by using conventional learning strategies rejected $(\mathrm{Fh}>\mathrm{Ft})$. It means there is a very significant difference results between students who have a positive attitude and taught by concept mapping learning strategies with students who taught by using conventional learning strategies.

3. The zero Hypothesis (Ho), which is stated that the average score of student of the ethics of public administration with a negative attitude and taught by using concept mapping learning strategy had no differences with the student who taught by using conventional learning strategies rejected $(\mathrm{Fh}>\mathrm{Ft})$. It means there is a very significant difference results between students who have a negative attitude and taught by concept mapping learning strategies with students who taught by using conventional learning strategies.

4. The zero hypothesis (Ho) which is stated that there is no interaction between the learning strategies and attitudes of students of public administration UNIDA Bogor rejected (Fh> Ft). It means there is a very significant interaction effect between learning strategies and students` attitude.

The results of the analysis of Turkey test at significance level $(\alpha)$ 0.05 can be seen in the following table.

Table of results analysis of Advanced Stage with Tukey Test

\begin{tabular}{|l|c|l|l|l|l|}
\hline $\begin{array}{l}\text { Group } \\
\text { Comparison }\end{array}$ & $\mathrm{n}$ & $\mathrm{K}$ & $\begin{array}{l}\mathrm{fd} \\
(\mathrm{k}-1 ; \mathrm{n}-\mathrm{k})\end{array}$ & $\begin{array}{l}\text { Average } \\
\text { Difference } \\
\text { Absolute } \\
\left(\mathrm{q}_{\mathrm{o}}\right)\end{array}$ & $\begin{array}{l}\mathrm{F}_{\text {table }} \\
\alpha 0,05\end{array}$ \\
\hline $\begin{array}{l}\text { Concept Mapping Strategy } \\
\text { and Conventional }\end{array}$ & 42 & 2 & $(1 ; 82)$ & $8,64^{*}$ & 3,96 \\
\hline $\begin{array}{l}\text { Concept mapping strategy } \\
\text { and Conventional Positive } \\
\text { attitude }\end{array}$ & 21 & 4 & $(3 ; 80)$ & $24,475^{*}$ & 2,72 \\
\hline $\begin{array}{l}\text { Concept mapping strategy } \\
\text { and conventional Negative } \\
\text { attitude }\end{array}$ & 21 & 4 & $(3 ; 80)$ & $6,119^{*}$ & 2,72 \\
\hline
\end{tabular}

Description:

*) = significant to level $\alpha 0,05$ $\mathrm{fd} \quad=$ Freedom Degree

$\mathrm{n} \quad=$ Sample Total

$\mathrm{k} \quad=$ Group Total

Based on the analysis stage further by using Tukey's test as the above table shows that:

1. The first research hypothesis stated that the learning outcomes of the ethics of public administration students who taught by using concept mapping learning strategies is higher than students who taught by using conventional learning strategies. The average score of students who taught by using concept mapping is 26.5 , this is significantly higher than those who taught by conventional learning strategy with the score average 25.57.

2. The second research hypothesis stated that learning outcomes of the ethics of public administration students with positive attitude who taught by using concept mapping learning strategies is higher than students who taught by using conventional learning strategies. The average score of students who taught by using concept mapping and have positive attitude is 28.14 , this is significantly higher than those who taught by conventional learning strategy with the score average 25.67.

3. The third research hypothesis stated that learning outcomes of the ethics of public administration students with negative attitude who taught by using conventional learning strategies is higher than students who taught by using concept mapping learning strategies. The average score of students who taught by using conventional learning strategy and have negative attitude is 25.48 , this is not significantly higher than those who taught by concept mapping learning strategies with the score average 24.86 .

Based on the above and the advanced stage of analysis of learning outcomes by using Turkey Test as in the table above, we can get some points as this following:

1. The influence of learning strategies on learning outcomes of students of ethics public administration who have positive attitude is very significant.

2. The influence of learning strategies on learning outcomes of students of ethics public administration who have negative attitude is very significant

3. The influence of learning strategies on learning outcomes of students of ethics public administration by using concept mapping learning strategy is very significant

4. The influence of learning strategies on learning outcomes of students of ethics public administration by using conventional learning strategy is very significant

\section{Conclusion}

The lecturers of ethics of public administration's subject should no longer "taught" but rather "learn" corresponds to the concept of mapping learning strategies. Concept mapping Learning Strategies are recommended to apply as an alternative learning strategies in addition to conventional learning strategies. Concept mapping learning strategies is more effective for certain students, as an alternative solution to improve student learning outcomes. Faculty of Social Universitas Djuanda Bogor as an institution is recommended to conduct training on an ongoing faculty continuously in order to improve the quality of the faculty that will ultimately provide an adequate number of teachers, highly competitive, skilled, competent for the implementing and developing a range of learning strategies including concept mapping. The results of the study suggested, could be used by friends in the environmental profession FISIP Universitas Djuanda Bogor, because the concept mapping learning strategy can be implemented as an alternative learning strategy, in addition to the existing strategies such as conventional. It is intended to improve the quality of student learning outcomes and is also the development of the learning process. 


\section{References}

[1] Miarso YH. Menyemai Benih Teknologi. Jakarta: Penerbit Kencana; 2005.

[2] Widyastini IG. Unsur-Unsur Filsafat Ilmu. Yogyakarta: UGM Press; 1992.

[3] Ali M. Pengantar Filsafat dalam Filsafat Ilmu sebagai Dasar Pengembangan Ilmu Pengetahuan. Klaten: Zintan Paruwara; 1997.

[4] Seels, Richey. Instructional Technology: the definition and domains of the field. Washington DC: Association for Educational Communication and Technology; 1994.

[5] Carey Da. The Systematic Design of Instruction. Boston: Boston Pearson; 2005.

[6] Briggs Ga. Kondisi Belajar dan Teori Pembelajaran. Jakarta: Pusat Antar Universitas Dirjen DIKTI; 1990.

[7] Suparman A. Desain Intsruksional. Jakarta: Dirjen DIKTI Depdikbud; 1997.

[8] Snead GL, Wycoff J. Lindmapping Your Personal Guide to Exploring Creativity and Problem-Solving. New York: Institute International Granklin; 1991

[9] Stahl RJ. Essentials of Educational Measurement. New Jersey: New Jersey Prentice; 1979.

[10] Grayson W. Concept Mapping and Curriculum Design ( The University of Tennesses at Chattanooga).

[11] Martin, Briggs LJ. The Affective and Cognitive Domains: Integration for Instruction and Research. Englewood Cliffs N.J: Educational Technology Publication Inc.; 1986.

[12] Buzan T. Gunakan Kepala Anda: Teknik Berpikir, Belajar dan Membangun Otak: Pustaka Delaprasta; 1999.

[13] Lau, B J, Shani AR. Behavior in Organization: An Experiential Approach. Homewood: Richard Irwin Inc.; 1992.

[14] Fishbein, Ajzen. Attitude, Intention and Behavior: An Introduction to Theory and Research. Philipines: Addison-Wesley Publishing Company Inc.; 1975.

[15] R B, Kendler FB. Psychology Understanding Human Incognitive Domain. London: Longman Group Ltd.; 1956.

[16] Shoemaker RM. Diffusion of Innovation: Third Edition. New York: Mac Millan Publs. Co Inc. Avenue; 1983.

[17] Fred, Kerlinger. Asas Asas Penelitian Behavioral. Yogyakarta: UGM Press; 2000. 